\title{
YOUNG FARMERS AND SUSTAINABLE DEVELOPMENT
}

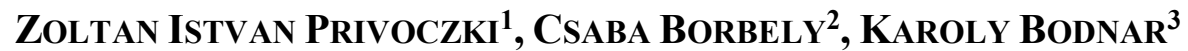 \\ ${ }^{1}$ AGRO-ASSISTANCE KFt., H-6640, Csongrad, Erzsebet u. 20., Hungary \\ ${ }^{2}$ University of Kaposvár Faculty of Economic Science, \\ H-7400, Kaposvar, Guba Sandor u. 40. \\ ${ }^{3}$ University of Szeged Faculty of Agriculture, H-6800, Hodmezovasarhely, Andrassy ut 15. \\ agrarpalyazat@gmail.com
}

\begin{abstract}
Agriculture, including land cultivation and livestock breeding, still has an important part in preserving the quality of life of the rural population in Hungary. Therefore, it is an important break-out point of the aging domestic agricultural sector to recover the willingness of "young farmers" for agricultural production. The restructuring of the agricultural society by qualifications, age, gender, and the chosen production form is still in progress at present. Thus, it is a national economic interest, and also a task to ensure a steady supply of young farmers. Farming in the spirit of sustainable development is a multi-actor field where learning imposes responsibility not only on the young farmers themselves but also on the groups continuously training them. This value-creating knowledge, work and experience are essential to be handed down from generation to generation. A spectacular growth can be achieved on the farms controlled by professionally well qualified farmers with a sustainable farming approach, thus better contribute to the development of the country. Sustainable management will not remain theoretical knowledge only, but also integrates into everyday life and will be the base of the farming business.
\end{abstract}

Keywords: young farmers, sustainable development, agricultural sector, agricultural society

\section{INTRODUCTION}

The Hungarian Government has adopted the Community Support Framework (CSF) in May 2003 and created the Agricultural and Rural Development Operational Program (ARDOP) in 2004 in relation to this. One element of this action programme was among the first to formulate and recognize the social and economic problems of the young farmers and to declare the concept of "young farmer". The program makers, similarly to the international trends, observed the increasingly unfavourable age structure and headcount ratio of the labour force engaged in agricultural activity in Hungary. They endeavour to improve it and they realized that it is important for the future of agriculture in terms of well-trained and skilled entrepreneurs to establish an economically viable enterprise, to create jobs and not only sustain the individual and the family. This discovery later became the basis for a number of professional articles on the subject, analysing the case history, the present course and future development of the situation, providing guidance for remedy. In Hungary, agriculture contributes approximately $4 \%$ to the GDP, which is slightly higher than the European average. The importance of agricultural sector in the national economy is shown by the fact that in addition to tourism it is only agriculture that has a positive trade balance. In 1999, there were 275 thousand people employed in agriculture, forestry and fishing sector altogether, in 2005 only 194 thousand, while in 2008 it dropped to 174 thousand (HANTOS, 2010).

In our country, 5.3 million hectares of agricultural land are cultivated; less than $5 \%$ of the population - 174 thousand people - work in agriculture and their numbers are steadily declining (NAGY, 2015). 90\% of the agricultural area is cultivated by approximately 180 thousand farmers (PÓLYA, 2014). The number of the population living from agriculture is currently less than 200 thousand people can be made, this number should be closer to 500 
thousand that was 25-30 years ago. If the sustainability of agriculture does not increase, the rural areas of will be declined and we can reckon with continuing impoverishment. (LÁZÁR, 2015) The AGRYA (Hungarian Association of Young Farmers) and CSO (Central Statistical Office) carried out joint research. Their research programs focused primarily on the generation issues of young farmers. In the analysis, it was found that the share of agriculture in the GDP of Hungary was 3-4\%, while taking into account the sectors built on agriculture it is $10-12 \%$. Considering the year of 2014 the number of businesses engaged in agricultural activities was 8442 and 485 thousand private farms were registered. $31 \%$ of farmers are over 65 years old, and the average age is 56 years. 61 763 young farmers were recorded also in the year of 2014 , which is $12.8 \%$ of the total number of farmers. The average age of young farmers is 34 years, out of which $77 \%$ were male, and 23\% female (LACZKA, 2014).

In the long term in Hungarian agriculture the further decline in the agricultural workforce should be avoided. Today, there are two important reasons why the number of employees in agriculture must be stabilized. One reason is that the level of domestic employment rate has to be increased, and in case of the rural population with low skills it can be improved only in this sector of the national economy. The other reason is that although there was an increase in agricultural productivity in recent years, its fundamental cause was the strong decline of the share of the livestock sector (NAGY AND BARÁTH, 2015).

\section{MATERIAL AND METHOD}

Today's biggest problem is the gap between the "three legs" of sustainability (natural, social, and economic) keeps growing. Rather than the quantitative growth of economy, the improvement of the harmony among nature, society and economy would be a goal, the way to which would be through qualitative changes. Rural depopulation, and aging would make the functioning of the economy impossible. Therefore, an integration based on cooperation should be created in which all businesses find their own place, role and reinforce each other (LUDA, 2012).

These ideas offer an alternative of the rural way of life that cannot be imposed on the young generation, and without the "young farmers" a successful agricultural and rural development policy is unconceivable. The term "sustainable development" is used to express that the quality of human life should be improved, and all the while the lifesupporting ecosystems remain inside the load-bearing ability.

Multifunctional agriculture is one that fulfils all production, ecological, environmental, regional and social functions that society expect. It can be distinguished from a one dimensional agricultural concept that focuses, for example, only on the production of food, while other tasks are not taken into account.

Sustainable agriculture is a kind of agriculture that is permanently able to manage both of these types of functions. On the one hand it can be fulfilled by applying sustainable production methods. For example, by observing the rules of water legislation demands and by way of compliance with animal welfare standards, on the other hand, by the admission to compensate for the higher costs of this production, these farming methods, and by remunerating the environmental, social and regional performance (KOPASZ, 2004).

The young farmers of today's Hungary must meet the criteria of both of sustainable, and multifunctional agriculture, however, if they cannot adapt to the changed economic and social conditions, they can be segregated, their production potential and mood can be reduced and they might become unemployed. 
Among the global challenges facing agriculture there is the climate change that determines the trend of development. The rising young agricultural generation must adapt to this. The increasing demand for food (quantity, quality, and safety) challenge young farmers in a way that makes it essential to monitor continuously the technical development of agriculture and the application of the results of innovation, along with environmental sustainability. The goal is to acquire a high level, technically advanced and environmentally sustainable management of young farmers. The precision plant cultivation and genetic engineering are the tools for sustainable field management.

The use of innovative agricultural technology the acquisition of which is essential for young farmers, is a relative advantage, however, it is associated with additional investment needs (TAKÁCS GYÖRGY, 2015).

This is the task of the successfully operating Agricultural Knowledge System (AKS) in Hungary. The Agricultural Knowledge System, that is knowledge creation, knowledge transfer and innovation institutions, and their services are used especially by young farmers. This is due to the fact that the structure and content of the knowledge necessary for the operation of socio-economic subsystems in rural areas has changed, now it goes well beyond agriculture in the strict sense of the word.

The official / formal agricultural knowledge system (AKS) has three main functions: (1) research, (2) education and consultancy (3), which together support the implementation of agricultural policies. The AKS in Hungary, by substantial public support, includes a variety of institutions (ministries, universities, research centres, education and agricultural advisory services). The result of their operation will contribute to the food supply security of young farmers using these services and also to the prosperity of rural development opportunities in Europe (NEMES AND VARGA, 2014.).

\section{RESULTS}

The shrinkage of the income generating ability agriculture (particularly in the livestock sector) threaten young farmers with the big dangers. The volume of agricultural commodity production, the volume of sales is vital not because of theoretical, or fiscal possibilities, but because of the lack of alternative livelihoods. Today, the main incentive for economic restructuring is the transformation of the ownership system (SÜLI ZAKAR AND BARANYAI, 1996). The production is based land, which is available only in limited quantities. The "Land to the farmers!" Programme as well as the changed Land Sales Act, which favours the young, local farmers with livestock economy in purchasing land, only slightly relieved the situation. The alleged unjust land rentals and land auctions make the young agricultural entrepreneurs socially fragmented and cause tensions. Production, including food and feed production, becomes more and more the duty of young farmers (native farmers, private entrepreneurs) and/or companies owned or controlled by young farmers. Because of today's ownership restructuring the agricultural population is divided on the question what kind of organizational structure they intend to farm, and whether they want to participate in it full time, as their main occupation or in part time, as a secondary activity.

Because of the declining tendency of the agricultural use of resources it is necessary to explore and analyse other, non-agricultural ways of use. Rural development pays special attention to the needs of non-farming rural population and to meet the needs young farmers who are not agricultural producers and meanwhile, "they focus on the possibilities of the non-agricultural utilisation of the agricultural resources." There is high potential in the processing and the local sales of local products, since bypassing intermediaries the young 
farmers could increase their income. It also will have a significant role in the development of the social sector because, in addition to creating new jobs, it is also designed to ensure the appropriate level of care for the rural population. The revival of old handicraft traditions can have dual purpose, one is to provide employment opportunities, and on the other hand, it helps the preservation of local cultural values. The touristic offer supplied with other resources of the particular region (folk music, folk dance) can be built on these values. The potential of tourism options (natural and human resources) could be an important alternative source of income for young farmers. However, it should be noted that of course this form does not provide an equal chance for each settlement and region, but where there is potential for tourism marketing should take advantage of it. However, the development of tourism cannot be a spontaneous process, it will definitely need conscious government, regional and local support (HEKLÉDINÉ HERBÁLY, 2002).

Several forms of tourism are linked to farming (horse riding, hunting, fishing, rural and farm tourism, etc.), and thus they mean important complementary activities for the area and the young farmers working there.

- tourism could create local markets for agricultural products, better prices for exports are available by savings in packing, shipping and customs duties, or - by achieving a higher processing level - in the case of catering consumption;

- in addition to profitability, it could expand employment, create new jobs and increase the skill level young farmers with preparation for these;

- $\quad$ it could help preserve and revive the traditions (embroidery, pottery and other folk crafts, folk songs, dances, folk customs, etc.), at the same time contributes to making rural life more comfortable and more modern by increasing the earnings and the dissemination and services;

- it could contribute to the development of infrastructure and services, as well as speed up the urbanization process.

\section{CONCLUSIONS}

The unfavourable market environment, the low profitability and high levels of expectation, bureaucratic law and penal sanctions, and the limited agribusiness segments discourage the would-be young farmers and greatly affect their development prospects. In contrast, the unique pre-financing forms $(+10 \%)$ and the broad financial possibilities, the production of high labour-intensive products, the possibility of family traditions tracking, and the security offered by advocacy associations encourage and promote young farmers to produce! Despite the difficulties, it is a break point to update the ageing Hungarian agrarian society that individual businesses managed by young farmers can achieve spectacular growth with the help of EU and national funds, and thus they better contribute to their own and the country's improvement and also to sustainable development. I believe that an important breakthrough point of the aging Hungarian agricultural sector could be the recovery of young farmers' willingness to produce. To do this, environmental factors of production traditions and the right incentive system in that area is needed. As I see it, the base of the system are the benefits to be provided for young farmers, gaining back the prestige of the profession and the recovery of beneficial agricultural support measures is also necessary. In addition to of the love of farming, and cherishing traditions of land cultivation and animal husbandry, the businesses founded by young farmers must serve national economic interests, such as increasing agricultural gross domestic product (GDP), 
or at least maintain the current level to be capable of self-sufficiency and keep up the family.

\section{REFERENCES}

HANTOS, K. (2010.): Hatékony generációváltás elősegítése a mezőgazdaságban - A fiatal gazdák támogatása. Budapesti Corvinus Egyetem Tájépítészeti és Tájökológiai Doktori Iskola (PhD) értekezés pp. 31.

HEKLÉDINÉ HERBÁLY, K. (2002): A mezőgazdasági erőforrások többirányú hasznosítása a vidékfejlesztésben. Budapesti Közgazdaságtudományi és Államigazgatási Egyetem Agrárközgazdasági Tanszék PhD értekezés pp. 52.

KopAsz, M. (2004.): A fenntartható magyar mezőgazdaság Budapesti Corvinus Egyetem Agrár-közgazdasági Ph.D. Program, Budapest pp.29.

LACZKA, É. (2014.): KSH elnökhelyettes előadás AGRYA és Második Hullám Vidéki Ifjúsági Szövetség közös konferenciáján, Budapest 2014.

LÁzÁR, J. (2015.): Miniszterelnökséget vezető Miniszter Makói Nemzetközi Hagyma és Gasztronómiai Fesztivál Mezőgazdasági fórumbeszéd, Makó 2015.

LuDA, Sz. (2012.): Értékelvű agrárvállalkozók szerepe a vidékfejlesztésben. In: Fenntartható fejlődés, élhető régió, élhető települési táj 2. Budapesti Corvinus Egyetem, Budapest, pp. 54.

NAGY, Zs., BARÁTH, L. (2015.): A többtényezös termelékenység és a környezeti állapot változása a magyar mezőgazdaságban, az EU-csatlakozást követően. Statisztikai szemle 93. évfolyam 1. szám.

NAGY, Zs. (2015): A Fiatal gazda támogatások szerepe a mezőgazdaságban. Debreceni Egyetem Gazdaságtudományi Kar 2015. pp. 8.

Nemes, G., VARGA, Á. (2014): Régi intézmények, új kihívások - a Mezőgazdasági Tudásrendszer (MTR) Magyarországon. Az átalakuló, alkalmazkodó mezőgazdaság és vidék. Károly Róbert Főiskola, Gyöngyös, pp. 1140.

PÓLYA, Á. (2014.): Mezőgazdasági termelők gazdaságfejlesztési tervei és annak irányai (AgroStratégia)

SÜLI-ZAKAR, I., BARANYAI, B. (1996): A mezögazdaság jövője, avagy a fenntartható fejlődés esélyei az Alföldön. Tér és Társadalom, 10. 4. pp.131.

TAKÁCS GYÖRGY, K. (2015): Mezőgazdasági innováció és a fenntartható fejlődés. Károly Róbert Főiskola; LVII. Georgikon Napok Keszthely pp. 395-396. 